\section{The Sustainability of China's Recovery from the Global Recession}

\author{
Nicholas R. Lardy
}

Nicholas R. Lardy is the Anthony M. Solomon Senior Fellow at the Peterson Institute for International Economics. He joined the Institute in March 2003 from the Brookings Institution, where he was a senior fellow from 1995 until 2003. He served at the University of Washington, where he was the director of the Henry M. Jackson School of International Studies from 1991 to 1995. From 1997 through the spring of 2000, he was also the Frederick Frank Adjunct Professor of International Trade and Finance at the Yale University School of Management. He is author, coauthor, or editor of numerous books on China, including The Future of China's Exchange Rate Policy (2009), China's Rise: Challenges and Opportunities (2008), Debating China's Exchange Rate Policy (2008), and China: The Balance Sheet-What the World Needs to Know Now about the Emerging Superpower (2006). The research underlying this policy brief was supported by a grant from the Peter $G$. Peterson Foundation.

(c) Peter G. Peterson Institute for International Economics. All rights reserved.

China's policy response to the global financial and economic crisis was early, large, and well-designed. Although Chinese financial institutions had little exposure to the toxic financial assets that brought down many large Western investment banks and other financial firms, China's leadership recognized that its dependence on exports meant that it was acutely vulnerable to a global recession. Thus they did not subscribe to the view sometimes described as "decoupling," the idea that Asian countries could passively weather the financial storm that originated in the United States and other advanced industrial economies. They understood that absent a vigorous policy response China inevitably would suffer from the backwash of a sharp economic slowdown in its largest export markets-the United States and Europe.
While it is now widely understood that China was the first globally significant economy to begin to recover from the crisis, critics nonetheless increasingly charge that the stimulus program has substantial flaws and that China's early economic recovery cannot be sustained. One prominent critic has gone so far as to suggest that the stimulus has created a debt-fueled bubble that will collapse, causing China's growth to plunge to only 2 percent. ${ }^{1}$ But the analysis below suggests these criticisms are exaggerated.

\section{CHINA AND THE CRISIS}

In the fall of 2007, just before the global crisis, the Chinese authorities tightened monetary policy and took steps to curtail an incipient property bubble. But when the global crisis intensified in the fall of 2008 the authorities reversed economic course by launching a policy of monetary easing in order to offset the additional drag on China's growth caused by the sharp slowdown in global trade. First, they cancelled the lending quotas that had previously restricted the ability of banks to fully meet the demand for loans from their customers. ${ }^{2}$ Second, to ensure that a sufficient supply of funds would be available to meet this demand, the government repeatedly reduced the share of deposits that banks had to place with the central bank. Banks were not necessarily forced to expand their lending in 2009, as has often been asserted. It was in their economic self-interest to do so since the interest rate that they could charge on loans was several times what they earned either on funds they were required to place with the central bank or on funds lent in the interbank market. ${ }^{3}$ Thus, the

1. Aki Ito and Patrick Riai, "Rogoff Says China Crisis May Trigger Regional Slump," February 24, 2010, www.bloomberg.com (accessed March 5, 2010).

2. Mao Lijun and Wang Bo, "Lending Caps to Reduce Liquidity," China Daily, January 21, 2010, 10.

3. The central bank pays 1.62 percent on reserves and in December 2008 interbank market lending rates ranged from 1.0058 percent for loans of onemonth maturity to 2.3579 percent for loans of one-year maturity. In contrast, in December 2008 the average interest rate on a one-year loan was 6.64 percent; see People's Bank of China, Monetary Policy Analysis Small Group, Report on the Implementation of Monetary Policy, Fourth Quarter 2009, February 11, 2010, 6, 11, and 21, www.pbc.gov.cn (accessed on February 11, 2010). 
government's first step in monetary easing was to increase the supply of loanable funds.

The authorities simultaneously took steps to increase the real demand for loans. First, they repeatedly lowered the benchmark interest rates that guide the rates that banks charge on loans of various maturities. These cuts took the benchmark rate on a five-year loan from 7.74 percent in September 2008 to 5.76 percent at year-end. Second, they made deeper cuts in the rates for mortgage loans. Prior to the fall of 2008 the rate that applied to mortgage loans that banks made to individuals to purchase owner-occupied property was 0.85 times

\section{Much of the criticism that is directed at}

\section{China's stimulus ignores or understates}

both the substantial advantages that accrue

to China as a result of coming through the crisis with strong economic growth momentum and fails to appreciate the steps

\section{that the authorities already have taken}

\section{that head off the potential adverse effects of the stimulus predicted by the critics.}

the benchmark rate. Beginning in September the government reduced this multiple to 0.7 . So, for example, the combined effect of a reduction in the benchmark five-year loan rate and the adjustment in the mortgage factor meant that the interest rate a potential home buyer would pay on a mortgage with a term of five or more years was reduced by two-fifths, from 6.66 to 4.16 percent. This meant that the monthly payment on a 20 -year mortgage was reduced by 18.6 percent. ${ }^{4}$ For property investors the 40 percent minimum downpayment on a mortgage, introduced in the fall of 2007, was scaled back to 20 percent. And the compulsory penalty interest rate that applied to property investors, which had been set at 1.1 times the benchmark rate starting in September 2007, was eliminated. ${ }^{5}$ A few months later, in January 2009, the authorities reduced to two years (from five years) the period investors must hold a

4. People's Bank of China, Monetary Policy Analysis Small Group, Report on the Implementation of Monetary Policy, Fourth Quarter 2008, February 23, 2009, 46, www.pbc.gov.cn (accessed on February 24, 2009).

5. Banks, however, were advised that they "should appropriately raise" the downpayment ratio and the interest rate on mortgages that were not for firsttime buyers, were not for owner-occupied units, and were for high-end rather than ordinary property. property in order to avoid a sales tax when a property is sold. ${ }^{6}$

The result of these policy initiatives was a massive increase in bank lending, particularly in the first half of 2009, when domestic currency loans outstanding increased by RMB7.4 trillion, three times the increase in the first half of 2008. Loan growth moderated substantially in the second half, so for the year as a whole bank lending in domestic currency increased by RMB9.59 trillion, about twice the RMB4.91 trillion increase in bank lending in domestic currency in 2008..$^{7}$ Mortgage lending was a large part of the loan expansion story in 2009. Individual mortgage loans outstanding increased by RMB1.4 trillion, about five times the increase of $2008 .^{8}$

Shortly after the authorities launched their policy of monetary easing in September 2008 they also announced a RMB4 trillion stimulus program, entirely devoted to investment expenditures. This program began immediately in the fourth quarter of 2008 and extends through 2010. In practice the stimulus program is closely linked to monetary easing since the plan from the outset was that it would be financed primarily by increased bank lending rather than through the government budget.

The results of China's stimulus program were impressive, making China the first globally significant economy to begin to recover from the global economic recession. Measured on a quarter-over-quarter basis the economy bottomed out in the fourth quarter of 2008, when economic growth slowed to only 4.3 percent. As the stimulus package began to take hold China's growth accelerated sharply to 9.5 and 11.4 percent, respectively, in the first and second quarters of 2009. In January 2010 the statistical authorities placed the year-over-year GDP growth in 2009 at 8.7 percent, well above the pace that most external observers had expected a year earlier. ${ }^{10}$

\section{SHORTCOMINGS OF THE STIMULUS?}

China's growth in 2009 was impressive compared with the absolute downturns in economic output in the United States, Europe, Japan, and many other developed economies and

6. "China Imposes Tougher Home Sale Tax to Control Bubble," People's Daily Online, December 10, 2010, http://english.people.com (accessed on December 10, 2009).

7. People's Bank of China, Monetary Policy Analysis Small Group, Report on the Implementation of Monetary Policy, Fourth Quarter 2009, 3.

8. People's Bank of China, Monetary Policy Analysis Small Group, Report on the Implementation of Monetary Policy, Fourth Quarter 2009, 48.

9. People's Bank of China, Statistical Investigation Office, An Analysis of Macroeconomic Trends in the Fourth Quarter of 2009, January 29, 2010, www. pbc.gov.cn (accessed on January 30, 2010).

10. National Bureau of Statistics of China, National Economy: Recovery and Posing in the Good Direction in 2009, January 21, 2010, www.stats.gov.cn (accessed on January 21, 2010). 
was the fastest growth of any emerging market. But 2009 was the second consecutive year of slowing Chinese growth and 8.7 percent was the slowest pace of expansion recorded since 2001. Moreover, critics, both in China and abroad, argue that growth recovery in 2009 was unsustainable since it relied on a burst of investment financed largely by an unprecedented increase in bank lending. ${ }^{11}$ According to the critics, the massive stimulus program would have several adverse consequences. First, in the short run it created bubbles in the property and equity markets as funds lent for investment leaked into these markets. Second, in the medium term the massive investment program financed with the expanded supply of credit would inevitably lead to excess industrial capacity and thus, with a slight lag, would put downward pressure on prices and firm profits. ${ }^{12}$ That, in turn, would impair the ability of firms to amortize their bank debt and thus likely lead to a large increase in nonperforming loans. Potentially this would require the state to recapitalize the banks once again, with adverse consequences for the government's fiscal position.

Third, the critics argue that the stimulus undermines China's strong fiscal position. China's budget deficit barely topped 2 percent in 2009, a small fraction of the deficits recorded in the United States and some other advanced industrial countries. This meant China's outstanding government debt remained stable at only 20 percent of GDP, again a small fraction of most high-income economies. But, the critics charge, this obscures a massive increase in hidden government debt.

Finally, the critics charge that the stimulus program exacerbated China's structural imbalances and set back the effort to transition to growth that would rely more on the expansion of private consumption expenditure rather than the growth of investment and exports. ${ }^{13}$

While China's economy is marked by substantial imbalances, all of these criticisms of China's stimulus program seem exaggerated. At a minimum they do not recognize adequately that the alternative to the massive stimulus program was an even sharper drop in economic growth. Moreover, while China faces a substantial challenge in sustaining economic growth in a postcrisis world, its immediate challenge is similar to that faced by many other countries- how soon and at what pace to reduce its stimulus.

11. Stephen Roach, "An Unbalanced World Is Again Compounding Its Imbalances," Financial Times, October 7, 2009, 23.

12. European Chamber, Overcapacity in China: Causes, Impacts and Recommendations, November 26, 2009, 20, www.europeanchamber.com.cn (accessed on March 3, 2010).

13. Michael Pettis, "Sharing the Pain: The Global Struggle Over Savings," Carnegie Policy Brief 84 (Washington: Carnegie Endowment for International Peace, November 2009); "China Has Been Misread by Bulls and Bears Alike," Financial Times, February 26, 2010, 11.
Much of the criticism that is directed at China's stimulus ignores or understates both the substantial advantages that accrue to China as a result of coming through the crisis with strong economic growth momentum and fails to appreciate the steps that the authorities already have taken that head off the potential adverse effects of the stimulus predicted by the critics. The criticism also gives short shrift to the advantages that accrue to China as a result of its long-standing very conservative fiscal and financial regulatory policies.

\section{Excessive Lending and a Property Bubble?}

The charge of excessive lending growth, for example, fails to take into account that the authorities initiated steps to slow lending growth as early as mid-2009. Increased window guidance and other initiatives slowed lending dramatically in the second half of the year. Although lending spiked upward in January 2010, the China Banking Regulatory Commission (CBRC) announced that month that it would take tougher measures to moderate the pace of lending over the balance of 2010. It reinstated mandatory lending quotas on individual banks and imposed tougher regulations to prevent banks from disbursing most of their lending quota in the first quarter or two of the year. ${ }^{14}$ It also raised the required reserve ratio by 50 basis points in both January and February, cutting banks' excess reserves and further signaling the transition away from the "moderately loose monetary policy" of 2009 to the "moderately loose monetary policy implemented flexibly" policy of 2010.

Second, the CBRC has taken other steps to curtail the expansion of bank credit. In October 2009, in what he described as a "historic decision," Chairman Liu Mingkang ruled that banks would no longer be able to count subordinated debt and hybrid capital as part of their tier-two capital. ${ }^{15}$

14. The aggregate quota for the increase in bank loans outstanding in 2010 was set at RMB7.5 trillion. Moreover, the CBRC announced that each bank should advance in each month no more than 12 percent of its annual quota and in each quarter no more than 30 percent of its annual quota. This would limit the expansion of loans outstanding to RMB900 billion per month, although the authorities acknowledged that this limit would be exceeded in January since the new regulations were not announced until the second half of January when new lending had already exceeded RMB1 trillion; see Mao Lijun and Wang Bo, "Lending Caps to Reduce Liquidity."

15. Liu Mingkang, "Chinese Bankers Carry Hopes for Future Balanced Development," speech to the Asian Financial Forum in Hong Kong, January 20, 2010, www.cbrc.gov.cn (accessed on February 18, 2010); "China Lenders Asked to Rein in Record Loans," Peoplés Daily Online, August 21, 2009, http://english.people.com (accessed on August 21, 2009). The main concern of the CBRC was that by 2009 a little over half of the subordinated bonds sold by banks had been purchased by other banks. These large cross-holdings of subordinated debt do not add any capital to the banking system as a whole, meaning that high capital adequacy ratios reported by individual banks 
During the lending boom of 2009 banks kept their capital adequacy ratios from falling sharply by selling large amounts of subordinated debt. ${ }^{16}$ Raising the required reserve ratio and disallowing subordinated debt as a source of capital now requires banks to either raise more equity capital or slow down their lending and other activities that require capital backing.

\section{Contrary to repeated criticisms,}

\section{this stimulus had a substantial}

\section{consumption component and focused on investment in infrastructure rather than expanding capacity in traditional industries such as steel.}

Third, just as they had in the fall of 2007 , the authorities focused special attention on moderating the growth of the property market. In December 2009 the government reinstated the 40 percent minimum downpayment for mortgages made to property investors and lengthened to five years the period that property investors must hold a property to avoid paying sales tax when a property is sold. ${ }^{17}$ Both these measures cut the potential profits of property investors and disincentivized speculators. These moves dramatically cut the pace of property sales in late 2009 and early 2010 and are likely to be followed by price moderation in the housing market.

Even if the government is less successful in moderating property prices this time around than it was in 2008 , it is important to recognize that even a major property price correction in China would not have the systemic implications that it had in the United States and several other major industrial countries in the current crisis. The reason is simple: There is much less leverage in China's property market than there

overstate the soundness of the banking system as a whole. Fang Huilei, Zhang Man, Chen Huiying, and Feng Zhe, "New Draft Rules on Subordinated Bonds Will Lower Banks' Capital Adequacy Ratios and Reduce the Systemic Risk of Cross-Holding," Caijing, August 24, 2009, http://english.caijing.com. cn (accessed on August 24, 2009).

16. The CBRC starting in 2004 allowed banks to issue subordinated debt, which under certain conditions could be counted as part of their tier-two capital. The volumes issued in 2009 grew rapidly, to RMB236.7 billion in the first half of 2009 alone; see "China Lenders Asked to Rein in Record Loans," People’s Daily Online, August 21, 2009, http://english.people.com.cn (accessed on August 21,2009). For the year as a whole, banks issued subordinated debt valued at RMB266.9 billion; see People's Bank of China, "The Financial Market Situation in 2009," February 2, 2010, www.pbc.gov.cn (accessed on February 2, 2010). Thus once the new CBRC draft regulation was circulated in August, bank issuance of subordinated debt halted.

17. "China Imposes Tougher Home Sale Tax to Control Bubble," People's Daily Online, December 10, 2009. is, for example, in the United States or the United Kingdom. This is seen most clearly in the ratio of household debt to disposable income.

The boom years in the United States and some other advanced industrial economies were fueled by a decline in the household saving rate and an increase in indebtedness, which allowed consumption to rise substantially more rapidly than household income, thus supercharging economic growth for a number of years. By the onset of the crisis, household indebtedness relative to disposable income (after-tax income) had risen to about 130 percent in the United States and even higher levels in the United Kingdom. In the United States much of this debt takes the form of mortgages, and in 2005 and 2006 an increasing share of new mortgages was underwritten on lax terms known as subprime. As long as housing prices continued to rise the increase in household leverage was manageable. But when housing prices began to correct many property investors, who had paid little or nothing down, simply walked away from their properties and defaulted on their mortgages. The value of securities backed by subprime loans plummeted, leaving major financial institutions in the United States and Europe with gaping holes in their balance sheets, which ultimately had to be plugged by massive infusions of government capital.

In contrast, Chinese households are substantially less leveraged. Just prior to the crisis at year-end 2007 loans outstanding to households, including mortgages, auto loans, credit card debt, loans to proprietorships, and seasonal working capital loans to farmers for the purchase of seeds and fertilizer, stood at RMB5.1 trillion or 34 percent of household disposable income. ${ }^{18}$

Not only are Chinese households much less leveraged than their counterparts in several major advanced industrial countries but also the share of their debt devoted to the purchase of property is relatively small. In part this reflects the high downpayment ratios that the CBRC requires as a precondition to qualify for a mortgage on a residential property. Moreover, the Chinese regulator has never approved the introduction of home equity lines of credit, which inevitably increase leverage as the lines are drawn down. In part low household leverage reflects the not uncommon practice in China of buying residential property entirely with cash. Of households' total borrowing at year-end 2007, mortgage debt accounted for RMB2.7 trillion, barely over half of all household debt, an amount equivalent to 18 percent of household income. In contrast, in the United States in the same year mortgage debt

18. People's Bank of China, "China’s Stable Financial Development in 2007," January 11, 2008, www.pbc.gov.cn (accessed on January 11, 2008); National Bureau of Statistics of China, China Statistical Yearbook 2009 (Beijing: China Statistics Press, 2009), 77. 
accounted for three-quarters of total household debt and was the equivalent of 100 percent of household disposable income. Put differently, relative to income, household mortgage debt in the United States is five times more than in China.

The point is simple: A housing price correction in a market with a relatively small amount of leverage has implications that are quite different from a price correction in a much more highly leveraged market. In the former case defaults are likely to be few in number since property price declines would have to exceed 20 percent before any owners reached negative equity. In the latter case, as in the United States, subprime loans frequently required no money down, so even a modest price correction put many owners into negative equity positions on their property. As these subprime borrowers defaulted on their mortgages and went through foreclosure, their properties came back on to the market, reinforcing the property price correction, and thus pushing even more borrowers into a negative equity position. As a result, defaults on subprime loans rose sharply and thus the value of securities backed by subprime and eventually even higher quality tranches of mortgages, such as Alt-A, plummeted. This threatened the viability of several major financial institutions that either held large amounts of such securities or had issued guarantees on the value of such securities.

\section{Creation of Excess Capacity?}

What about the assertion that the investment boom in 2009 created excess capacity that will lead to downward pressure on prices and thus on firm profits, perhaps leading to defaults on the loans that financed the capacity expansion? This argument too seems not well founded. In a high-growth, highinvestment economy, such as China's, some product sectors inevitably have at least temporary excess capacity. The issue, however, is whether this excess capacity is so widespread and enduring that it could contribute to deflation, putting downward pressure on the profits of a large number of firms across many sectors. Such a situation would not only impair the ability of individual firms to repay their loans but also potentially lead to large-scale losses in the banking system.

This does not appear to be the case in China for several reasons. First, Chinese firms historically have tended to hold on to outdated equipment, so that if demand for their product surged the firm could bring this old, higher-cost production capacity back on line. So Chinese data on excess capacity may overstate the extent of excess capacity compared with other countries. Second, there is a substantial difference between excess capacity of, say, 20 percent in a mature economy growing at 2 to 3 percent per year and 20 percent excess capacity in China, where growth has averaged about 10 percent for three decades. In the mature economy the cost of financing excess capacity for the seven or eight years it might take demand to catch up with potential supply would be substantial and probably put enormous financial pressure on the firms that had built the excess capacity. But in China 20 percent excess capacity would likely be absorbed in a year or two.

Steel is most commonly cited as an industry that has tended to excess capacity in China. A recent European Chamber report estimated that China's excess production capacity in steel at year-end 2008 was between 100 million and 200 million metric tons, which translates into excess capacity between 15 and 30 percent. ${ }^{19}$ This estimated overcapacity alone is more than the steel output of the two next largest global steel producers-Japan and the United States.

\section{The charge of excessive lending growth}

\section{fails to take into account that the authorities initiated steps to slow lending growth as early as mid-2009.}

But this analysis fails to adequately consider the pace of growth of apparent steel consumption in China, which has been over 15 percent annually between 2000 and $2008 .^{20}$ In 2009 China's apparent steel consumption soared by 107 million metric tons. In short, what appeared to outside observers to be massive excess capacity at year-end 2008 may have been mostly absorbed in 2009 . If not it will likely be absorbed in 2010 .

Finally, it is important to note that the stimulus-fueled investment boom of 2009 was not focused on expanding production capacity in China's traditional industries, such as steel, as is widely claimed. One important indicator of this is the sectoral allocation of medium- and long-term bank loans. These are loans of more than one year, which are used to finance fixed investment, as opposed to loans of a year or less, which are used to finance working capital. In 2009 medium- and long-term loans outstanding expanded by RMB4.9 trillion, accounting for almost half of the increase in renminbi lending by the banking system that year. Of these loans financing fixed investment, only 10.2 percent, or RMB502.5 billion, were extended to manufacturing firms. Fifty percent went to infrastructure projects, 13.1 percent to leasing and business services, and 10.2 percent to property. ${ }^{21}$

We can also examine the composition of investment,

19. European Chamber, Overcapacity in China: Causes, Impacts and Recommendations, November 26, 2009, 20.

20. Apparent steel consumption is steel production minus net exports. This series is compiled by World Steel Dynamics.

21. People's Bank of China, Monetary Policy Analysis Small Group, Report on the Implementation of Monetary Policy, Fourth Quarter 2009, 3. 
whether financed by medium- and long-term loans or by the internal cash flow of the corporate sector. Steel investment in 2009 was substantial, about RMB400 billion. But the growth of investment in the steel industry in 2009 was minimal, only

The stimulus did lead to a substantial increase in the borrowing of local investment companies... which local governments will have to repay ultimately...but the infrastructure provided through these companies likely will contribute to China's sustained economic growth and thus to increasing government tax revenues as well.

3 percent compared with an increase of investment for the economy as a whole of 30 percent. Again, this reflects the priorities of the stimulus program-more for infrastructure and less for traditional industries such as steel. Investment in the rail network, for example, rose 67.5 percent in $2009 .{ }^{22}$

\section{Hidden Government Debts Threatening Fiscal Sustainability?}

The third critique to examine is that China's stimulus has led to a massive increase in implicit government debt that ultimately could threaten government finances. Since the stimulus in 2009 was financed by credit rather than deficit spending, government debt remains low. But much of the medium- and long-term bank lending for infrastructure investment went to local quasi-government agencies, called local investment or platform companies. ${ }^{23}$ Although local governments legally are not allowed to borrow or to run budget deficits, lending to these local investment companies is legal. Critics argue that these platform companies are unlikely to be able to repay

22. These are increases in what the Chinese statistical authorities call fixed asset investment, a measure that overstates the growth of capital formation. While the data on fixed asset investment are biased upward the relative rates of expansion of fixed asset investment in steel compared with the economy as a whole is likely to be a good indicator of the modest growth of capital formation in the steel industry in 2009. National Bureau of Statistics of China,

"Main Statistical Data in 2009," January 21, 2010, www.stats.gov.cn (accessed on January 21, 2010).

23. These are also sometimes referred to in secondary sources as conduit companies or urban development and construction companies. these loans and that the obligation to repay will ultimately fall on local governments. The view that the repayment burden could fall on local governments is quite reasonable since in many instances local governments have provided guarantees for these loans.

How large might the debt of these platform companies be? To start with, consider medium- and long-term bank lending that the central bank specifically identifies as going to infrastructure projects. These loans amounted to RMB1.1 trillion and RMB2.5 trillion in 2008 and 2009, respectively. ${ }^{24}$ If we assume that all of these infrastructure loans went to local investment companies and that none of the loans of this type made in the five years 2005-09 has been repaid, the bank debt of these platform companies at year-end 2009 would have been RMB5.666 trillion. ${ }^{25}$ These firms also issue bonds, a reported RMB121.2 billion in 2009 , slightly more than what they issued in the previous four years. ${ }^{26}$ Adding bank borrowing and bond issuance brings the total debt of local investment companies to approximately RMB5.9 trillion.

An alternative to this bottom-up approach is to look for authoritative Chinese estimates of the debt. Ba Shusong, the deputy director of the Institute of Finance of the Development Research Center, a leading government think tank, placed the debt of local investment companies at mid-year 2009 at more than RMB5 trillion, up from about RMB1 trillion at the beginning of 2008. ${ }^{27}$ Adding medium- and long-term infrastructure lending by banks in the second half of 2009 and bond issuance by these firms in the second half to Ba's mid-year figure of more than RMB5 trillion brings the total debt to RMB6 trillion, very close to the bottom-up estimate just laid out. ${ }^{28}$

RMB6 trillion is equal to almost a fifth of China's GDP, roughly equal to the outstanding government debt issued by the Ministry of Finance and equal to 15 percent of all the loans

24. People's Bank of China, Monetary Policy Analysis Small Group, Report on the Implementation of Monetary Policy, Fourth Quarter 2008, 4; Report on the Implementation of Monetary Policy, Fourth Quarter 2009, 3.

25. Medium- and long-term infrastructure lending in 2005, 2006, and 2007 was RMB617.50 billion, RMB650.48 billion, and RMB 798.36 billion, respectively.

26. Andrew Batson, "China's Localities Feel Pinch of Tighter Credit," Wall Street Journal, February 25, 2010, http://online.wsj.com (accessed on February 25,2010 ). The issuance of bonds in the first 11 months of 2009 almost equaled bond issuance by these companies in the previous four years. Xu Lin, "Taming 'Local Government Inc.," China Reform 316, January 15, 2010, http://englishcaing.com.cn (accessed on March 12, 2010).

27. Wang Bo, "Systematic Risks Warning," China Daily, November 9, 2009, 7.

28. In the second half of 2009 banks extended RMB900 billion of mediumand long-term loans for infrastructure and local investment companies issued RMB55.2 billion in bonds. See Xu Lin, "Taming 'Local Government Inc.” 
outstanding from the banking system. ${ }^{29}$ In short, by almost any standard the borrowing of local platform companies is large.

Judging the platform companies' ability to service their debt is difficult. One concern is that some services provided by these quasi-government agencies are substantially underpriced. Despite increases in tariffs over the last decade or more, most local water companies have lost money every year since the mid-1990s. ${ }^{30}$ Similarly, the fares on subway systems in China are so low that fare box revenue probably does not even cover operating costs. Thus the underpricing of these services impairs the ability of these quasi-government agencies to repay their loans. To the extent to which platform companies invest in activities that do not generate revenue, their ability to repay is even more impaired.

While the financial returns to some of the investments undertaken by platform companies may be modest, it is likely that the real economic returns of these investments to the economy as a whole on average will be high. China is in the midst of the largest rural-to-urban migration in global history. Thus the demand for services in urban areas is rising rapidly and the real economic returns to infrastructure investment are likely to be high. Indeed, unlike India, where insufficient infrastructure investment has been a brake on economic growth, rapid infrastructure development in China has facilitated and stimulated superior growth performance.

Moreover, while some local investment companies may have weak cash flow, they nevertheless have substantial assets. At year-end 2009 their assets amounted to RMB8 trillion, about one-third more than our estimate of their outstanding debt. ${ }^{31}$ Thus lending to these companies is not likely to have the same adverse consequences as did large-scale bank lending to chronic money-losing state-owned companies in the mid-1990s. At that time many of these state-owned borrowers had liabilities far exceeding their assets so when they were ultimately closed and liquidated banks recovered little or nothing. ${ }^{32}$ Ultimately, the government had to inject about RMB3.4 trillion into the banking system to facilitate its restructuring. ${ }^{33}$

29. This is substantially below Victor Shih's estimate of RMB11 trillion; see Victor Shih, "China's 8,000 Credit Risks," Asian Wall Street Journal, February 8, 2010, http://online.wsj.com (accessed on February 12, 2010). It is above a figure of RMB5 trillion given by the People's Daily, an agency of the Chinese Communist Party; see "China on High Alert for Large-Scale Bad Loans," Peoplés Daily Online, February 25, 2010.

30. “High Price for Water Reform?” People's Daily Online, October 29, 2009, http://english.people.com.cn (accessed on October 29, 2009).

31. "China on High Alert for Large-Scale Bad Loans," Peoplés Daily Online, February 25, 2010.

32. Nicholas R. Lardy, China's Unfinished Economic Revolution (Washington: Brookings Institution, 1998), 43,142-43.

33. Ma Guonan, "Who Pays China’s Bank Restructuring Bill?" CEPII
In short, local investment companies may be unable to repay a substantial portion of their borrowings. Ultimately, municipalities and other local governments will probably have to assume the responsibility for repaying much of the borrowing of the quasi-government agencies in their jurisdiction. But the infrastructure provided through local investment companies likely will contribute to China's sustained economic growth and thus to increasing government tax revenues as well. Moreover, local governments are likely to continue to enjoy substantial income from the leasing of land, revenue that is not reflected in local government budgets. Needless to say, if borrowing by local investment companies were to continue at the pace observed in 2008 and 2009 the outlook would be much less sanguine.

\section{Neglect of Consumption?}

The charge that the stimulus program focused excessively on expanding investment demand and has set back China's efforts to achieve more balanced growth by encouraging private consumption seems wrong. Consumption growth in 2009 was actually quite robust; indeed on the basis of preliminary data it appears that 2009 was the first year since 2000 that the growth of consumption outstripped the growth of GDP. Thus the long-term decline in the consumption share of GDP probably ended, at least temporarily, in 2009.

During a year in which GDP expansion was the slowest in almost a decade, how could consumption growth have been so strong in relative terms? In the early months of 2009 employment in export-oriented industries was collapsing, with a reported loss of 20 million jobs in export manufacturing centers along the southeast coast, most notably in Guangdong Province. ${ }^{34}$

Several factors explain this unexpectedly strong growth of consumption in 2009. First, the boom in investment, particularly in construction activities, appears to have offset a large portion of the job losses in the export sector. Thus employment of rural migrant workers, largely in construction as well as in coastal export industries, quickly recovered. And in the more formal labor market in urban areas, by year-end 200911.02 million jobs were created, very nearly matching the 11.13 million jobs created in $2008 .^{35}$

Working Paper No. 2006-4 (Centre D'etudes Prospective et D'informations Internationales, February 2006), 22.

34. "20 Million Migrants Lost Jobs: Survey," China Daily, February 3, 2009, www.chinadaily.com.cn (accessed on March 15, 2010).

35. Wen Jiabao, Report on Work of the Government, March 5, 2009, www.npc. gov.cn (accessed on April 13, 2009); Report on Work of the Government, March 5, 2010, www.npc.gov.cn (accessed on March 24, 2010). 
Second, the government continued to raise transfer payments to China's lowest income residents and to increase payments to those drawing pensions. Transfer payments to about 70 million of China's lowest income citizens rose by a third or RMB20 billion in 2009. ${ }^{36}$ Monthly pension payments for enterprise retirees increased by RMB120 or 10 percent in January 2009, almost double the 5.9 percent increase in consumer prices in $2008 .{ }^{37}$ This raised payments to retirees by about RMB75 billion. ${ }^{38}$ The increases in employment, transfer payments, and pension income contributed to a 9.8 percent increase in the disposable income of urban residents and an increase of 8.5 percent in the net income of rural residents in 2009. ${ }^{39}$

Third, the government, recognizing it could not rely entirely on increased investment to offset the drag on growth from shrinking exports, adopted several additional specific measures to encourage consumption as part of its stimulus program. In 2009 the government cut by half the 10 percent tax on vehicles with small-displacement engines. In addition the government allocated RMB45 billion in subsidies to rural residents trading in old vehicles and home appliances. These subsidies alone probably boosted rural consumption by more than 1 percent. ${ }^{40}$ These incentives contributed to an almost 50 percent increase in vehicle sales nationally and a massive increase in the sale of consumer durables in rural areas.

Fourth, substantial increases in household borrowing bolstered consumption in 2009. Loans outstanding to households grew by RMB2.5 trillion, almost four times the increase of 2008. ${ }^{41}$ RMB1.4 trillion of this was used to finance the purchase of housing. The remainder, RMB1.1 trillion, might be considered an upward bound estimate of the amount of this increased borrowing that was devoted to financing consump-

36. Ministry of Civil Affairs, "Statistical Communiqué on Program Development," March 5, 2010, http://files.mca.gov.cn (accessed on March 12, 2010).

37. This was the fifth consecutive year in which retirees from enterprises received increases in their monthly pensions; "China to Raise Pensions from 2010," People's Daily Online, December 23, 2009, http://english.people.com. cn (accessed on December 23, 2009).

38. Calculated based on an average of 51 million enterprise retirees in 2009.

39. National Bureau of Statistics of China, "Main Statistical Data in 2009," January 21, 2010.

40. RMB45 billion is equal to 1.7 percent of rural consumption expenditures in 2008. If rural consumption grew by as much as 10 percent in 2009 the subsidy would be equal to 1.5 percent of consumption in 2009 .

41. The increase in lending to households is a comprehensive measure that includes mortgages, credit card debt, auto loans, seasonal working capital loans to farmers to finance seed and fertilizer purchases, and loans to proprietorships and other unincorporated businesses. When farmers and proprietors have improved access to working capital from banks, they can devote more of the income from their farms and small businesses to personal consumption. tion expenditures. This is a substantial amount, in excess of 3 percent of GDP.

These factors combined boosted urban consumption, which accounts for three-quarters of private consumption expenditures, by 10.1 percent in real terms, well ahead of the pace of GDP growth.

\section{SUMMARY}

China faces major challenges in sustaining its economic growth in a period of weak global recovery, particularly in Europe. In 2009 China's net exports of goods and services dropped precipitously, resulting in a substantial drag on economic growth. ${ }^{42}$ To overcome this drag China launched a massive stimulus program, financed largely with bank credit. Contrary to repeated criticisms, this stimulus had a substantial consumption component and directed investment primarily toward infrastructure rather than expanding capacity in traditional industries such as steel.

But the stimulus did come at a cost insofar as it led to a substantial increase in the implicit debt of local governments. The authorities recognize flooding the economy with more credit is not the way forward and that they will have to take strong additional policy initiatives to sustain economic growth. These include raising the prices of inputs such as water, electricity, and other resource products as well as introducing realistic environmental taxes and fees. These reforms, as well as a more flexible exchange rate, would reduce the distortions that for much of the past decade have favored industrial growth and exports over services and consumption and would contribute to sustaining China's impressive longterm economic growth.

42. The drag was calculated at 3.9 percentage points by China's statistical authority. That means to achieve growth of 8.7 percent domestic demand increased by 12.6 percent, which is the fastest pace of increase in domestic demand in more than a decade.

The views expressed in this publication are those of the author. This publication is part of the overall programs 